\title{
Om at forstå Bibelen i den moderne verden
}

\author{
Skriften som grundlaget for en verden af tegn med fire \\ dimensioner ${ }^{1}$
}

\section{Professor Dr. D. mult. Gerd Theissen}

\begin{abstract}
The article gives an outline of New Testament hermeneutics based on a hermeneutic of religion. Religions are sign worlds constructed by human beings. They refer to transcendence, a foundational story, imply moral imperatives, and form a community. The Bible is the basis of the Christian sign world that is constructed by two axioms (monotheism and Christology) and many basic beliefs. The Bible interprets and initiates religious experience. The basic religious experiences are: an amazement of the mystery of being, an experience of absolute confidence and of responsibility (cf. Ludwig Wittgenstein). These experiences pervade all four dimensions of the Bible: a kerygmatic message based in transcendence, a historical reference to the history Jesus, an ethical impact, and a canonical dimension, i.e. a relationship to churches. In modern times this implies a relationship to other religions. The article suggests therefore an edition of the Bible with an inter-religious appendix.
\end{abstract}

Key words: Biblical hermeneutics - religious experience - demythologization - sign world - cognitive study of religion - kerygmatic Christ religious commandments - canonical function.

Siden oplysningstiden er forståelsen af Bibelen blevet præget af en voksende distance mellem den moderne verden og de bibelske overbevisninger. Den teologiske hermeneutiks problem er netop denne distance: Hvordan kan en bog fra førmoderne tider kræve gyldighed til trods for denne store distance? Distancen er naturligvis også en chance. Afstanden muliggør, at man opdager noget nyt. Dette kan siges allerede om selve Bibelen. Det Gamle Testamente har været de første kristnes hellige skrift. Til trods for det havde de et kritisk forhold til deres bibel - i det mindste de hedningekristne: De opdagede

1. Forelæsning på Det Teologiske Fakultet på Københavns Universitet d. 2. september 2011. Jeg siger mange tak for bearbejdelsen af min danske tekst til Troels Engberg-Pedersen og Niels Henrik Gregersen. 
noget nyt i Bibelen netop på grund af deres distance i forhold til Det Gamle Testamente. De var sig bevidst, at alle udsagn vedrørte Israel. Men de tolkede dem ofte som udsagn om alle mennesker. De afviste omskærelsen og renhedsbuddene. De reciperede Bibelen selektivt og kritisk. De overholdt ikke alle de hellige bud. De opdagede en principiel ambivalens i Bibelen. Paulus siger: Bogstaven dræber, ånden giver liv (2 Kor 3,6). Selv hellige tekster kan misbruges. Kristendommen havde på forhånd et kritisk forhold til sine hellige skrifter. Dens senere historie er en kæde af hermeneutiske reformer, som igen og igen ville forstå Bibelen på en ny måde.

Den sidste store hermeneutiske revolution har været afmytologiseringsprogrammmet. Rudolf Bultmann offentligjorde det 1941, da Hitler var på højdepunktet af sin magt. Det var et kontraprogram imod de tyske kristnes moderniseringsprogram ${ }^{2}$, som ville frigøre det Nye Testamente fra jødiske tanker og motiver. Mange tyske kirker understøttede et institut, som blev grundlagt 1939 i Eisenach og som skulle rense kristendommen fra jødedommen. Nytestamentleren Hugo Odeberg fra Sverige samarbejdede og sympatiserede med instituttet. $^{3}$

Tesen, at det jødiske burde forsvinde, fandt en modtese hos Bultmann: Det var ikke det jødiske, der var problemet, men det mytiske: ${ }^{4}$ Og det mytiske skulle ikke elimineres, men fortolkes. Det mytiske modsiger nok den videnskabelige anskuelse af verden. Men myten har ifølge Bultmann ret $\mathrm{i}$, at den viser mennesket dets afhængighed. Myten siger: Mennesket er ikke i stand til autonomt (eigenmächtig) eller af egen kraft at skaffe sig det sande liv.

For Dietrich Bonhoeffer (1906-1945) 5 var det ikke det mytiske, som voldte problemer, men det religiøse. Han opfattede "religionen" som et forsøg på at udnytte menneskenes svagheder på en teologisk måde og at nedvurdere den dennesidige verden. Der er utvivlsomt en spænding mellem hans program om en "unreligiöse Interpretation biblischer Begriffe" (en ikke-religiøs fortolkning af bibelske begreber) og Bultmanns eksistentiale interpretation. For Bultmann var menneskets autonomi (hans Eigenmächtigkeit eller myndighed) synd vis à

2. Jf. Gerd Theissen, Neutestamentliche Wissenschaft vor und nach 1945. Karl Georg Kuhn und Günther Bornkamm (Heidelberg: Winter 2009), 195-227.

3. Vedrørende dette institut, se Susannah Heschel, The Aryan Jesus. Christian Theologians and the Bible in Nazi Germany (Princeton: University Press 2008) .

4. Rudolf Bultmann, "Neues Testament und Mythologie", i: Offenbarung und Heilsgeschehen (München: Kaiser 1941), 27-69.

5. Dietrich Bonhoeffer, Widerstand und Ergebung. Briefe und Aufzeichnungen aus der Haft, red. E. Bethge (München: Kaiser 1951). 
vis Gud. For Bonhoeffer var det netop den umyndighed, som religionen udnyttede, der var forkastelig.

Hvordan udviklede situationen sig efter krigen og frem til vore dage? De tyske kristnes program om at fjerne det jødiske var fuldstændigt kompromitteret. Men når man nu om dage kritiserer monoteismen for at være oprindelsen til vold og intolerance, så minder det mig en lille smule om forsøget på at fjerne det jødiske fra vores kultur. Monoteismen er jødedommens store arv. Et første kriterium for fortolkningen af Bibelen må derfor være: Bibelen skal tolkes således, at man ikke fornægter dens jødiske præg, og på en måde, som fremmer tolerancen mellem alle religioner.

Afmytologiseringsprogrammet blev først diskuteret i 1950erne, men mistede forbavsende hurtigt sin plausibilitet i 60erne. Kritikken af myndigheden kunne slet ikke forstås i et samfund, som ledte efter autonomi og emancipation (frigørelse). Dertil kommer, at postmodernismen i 80erne og 90erne bragte en fornyet positiv interesse for myten. Til trods for det gælder afmytologiseringens andet kriterium nu som før: Fortolkningen af Bibelen må være kompatibel med vores viden. Den må altså være kritisk - og det skal understreges: ikke alene historisk-kritisk.

Programmet om en ikke-religiøs fortolkning var kun et fragment. Før Bonhoeffer blev henrettet, havde han skrevet et manuskript herom, som er forsvundet. Dette program tabte sin plausibilitet, fordi interessen for religion voksede frem igen, mens interessen for Bibelen gik tilbage. Men samtidig voksede behovet for mere etisk orientiering. Den eksistentiale interpretation havde et etisk deficit eller underskud. Bultmann benægtede eksistensen af en særlig kristen etik. Bonhoeffer derimod havde skrevet en kristen etik. I denne henseende blev Bonhoeffers fordring om myndighed og dennesidighed aktuel i etisk henseende. Det tredje kriterium for fortolkningen af Bibelen må derfor være: Den må respektere menneskets autonomi og myndighed og må ikke negligere etiske motiver i Bibelen.

Alle tre hermeneutiske programmer fra 1940erne har været eksorcistiske hermeneutikker. Bibelfortolkningen havde den opgave at uddrive enten jødedommen eller mytologien eller religionen fra Bibelen. Jeg går derimod ind for en hermeneutik, som elsker jødedommen, som elsker myternes poesi og som afkoder religionens erfaringer af transcendens i teksterne. Ud over det var det altid ét tema i disse hermeneutikker, der blev gjort til nøglen til Bibelens forstålse. Hermeneutikken har været monotematisk. Men den skal være pluralistisk. Hvorfor det? 
Religionerne er tegnsprog eller tegnsystemer med fire dimensioner, som aldrig kan reduceres til et eneste tema. Religionernes mening er pluralistisk: ${ }^{6}$

- Religionerne indkoder i deres tekster erfaringer af transcendens.

- De begrunder sig selv ved hjælp af myter.

- De baserer sig på ethos og livsformer.

- De muliggør samfund ved hjælp af riter.

Religionens tegnsprog har som alle sprog en "grammatik" med regler for, hvordan deres tegn skal benyttes. Dens grammatik består af aksiomer såsom troen på den ene Gud eller troen på Kristus, derudover af mange grundlaggende motiver såsom omvendelse, tro eller stedfortrædelse. ${ }^{7}$ Den slags grundmotiver kan betragtes som religionens konstruktionsprincipper. De bestemmer, hvad der kan tillades eller ikke tillades $i$ en religion - ligesom en grammatik bestemmer, hvad der kan tillades som korrekt sprog. Det er ved hjælp af disse aksiomer og grundmotiver, at mennesker har opbygget deres religioner som semiotiske katedraler. Bibelen er grundlaget for sådan en semiotisk katedral: den kristne religion. Den er imidlertid ikke et system, som er lukket om sig selv, men den refererer til virkeligheden i fire dimensioner:

- Den har en reference til transcendensen, fordi det er religiøse erfaringer, som den indkoder. De vidner om den ene, sande Gud, som blev opdaget i Det Gamle Testamente.

- Den har endvidere en reference til historien eller rettere til historien i en mytisk skikkelse. Den refererer til hele Israels historie og i dens midte til Jesus fra Nazareth.

- Den har for det tredje en reference til moralen og etikken ved hjælp af bud og formaninger. Den vil præge hele livet gennem en bestemt ethos.

6. Jf. Gerd Theissen, Die Religion der ersten Christen. Eine Theorie des Urchristentums (Gütersloh: Gütersloher Verlagshaus 2000) = De forste kristnes religion. En teori om urkristendommen. Oversættelse og efterskrift ved Knud Rendtorff (Syddansk Universitetsforlag 2004). I denne bog har jeg fremstillet den kristne religion som en tegnverden af myte, ritual og etik. Den dimension af den religiøse erfaring har jeg udviklet i: Gerd Theissen, Erleben und Verhalten der ersten Christen. Eine Psychologie des Urchristentums (Gütersloh: Gütersloher Verlagshaus 2007).

7. En mere detaljeret beskrivelse af disse aksiomer og grundlæggende temaer jeg har prøvet at give i Gerd Theißen, Zur Bibel motivieren. Aufgaben, Inhalte und Methoden einer offenen Bibeldidaktik (Gütersloh: Gütersloher Verlagshaus 2003), 131-173. 
- Endelig danner dens riter grundlaget for et fallesskab. I Det Gamle Testamente er det alene Israels folk, i Det Nye Testamente er det den kristne menighed blandt folkeslagene.

En moderne hermeneutik må være kritisk i alle dimensioner. Ofte forstås ved kritik kun historisk kritik. Men nu til dags vedrører kritikken også referencen til transcendensen. Den spørger, om religionens henvisning til en transcendens er en illusion. Ideologikritikken vedrører referencen til livet og samfundet: Den spørger, om religionen er en skjult udøvelse af magt og skadelig for det sociale liv. Mellem religionskritikken og en bevarende religionshermeneutik findes der en "interpretationernes konflikt" (Paul Ricoeur). Den teologiske hermeneutik i Tyskland har ofte unddraget sig denne konflikt. Den fulgte Hans-Georg Gadamers hermeneutik, som fremfor alt havde tillid til traditionen: Vi forstår traditionen, fordi vi allerede i forvejen forstår den på grund af virkningshistorien. Jeg tilføjer: På den måde blev den bibelske virkningshistorie faktisk misforstået. ${ }^{8}$ For det hører med til Bibelens virkningshistorie, at religionen bliver kritiseret. Før vi som moderne mennesker beskæftiger os med religionen, har vi allerede forstået så meget om den, at vi ikke kan være indforstået med alt i religionen. Den franske konflikternes hermeneutik svarer langt mere til vores intellektuelle situation end indforståelsens hermeneutik fra Tübingen, omend sidstnævnte vidner om en stor kærlighed til Bibelen. ${ }^{9}$ Men en mere kritisk hermeneutik er nødvendig.

I det følgende giver jeg først en oversigt over Bibelens tegnverden og dens grammatik, d.v.s. over de aksiomer og grundmotiver, som danner det bibelske tegnsprogs arkitektur. Denne semiotiske hermeneutik, som beskriver religionen som et tegnsprog eller som en katedral, som er bygget ikke af stene men af tegn, er en beskyttelse imod at den bliver forvandlet til et stenbrud for nutiden. Derefter vil jeg udfolde én tankegang vedr. dette tegnsprogs reference til henholdsvis transcendensen, historien, livet og fællesskabet. Det drejer sig her om at nå frem til religiøse erfaringer $\mathrm{i}$ alle fire dimensioner, selv om religionen omfatter mere end erfaringer. Men jeg er overbevist om, at formidlingen af religiøse erfaringer begrunder Bibelens vedvarende gyldighed. Den semiotiske hermeneutik skal derfor fuldbyrdes gennem en hermeneutik af religiøse erfaringer.

8. Hans-Georg Gadamer, Wahrheit und Methode (Tübingen: Mohr-Siebeck1960).

9. Peter Stuhlmacher, Vom Verstehen des Neuen Testaments. Eine Hermeneutik (Grundrisse zum Neuen Testament; Göttingen: Vandenhoeck \& Ruprecht $\left.1979,1986^{2}\right)$. 


\section{Bibelens tegnsprog og dets grammatik}

Det bibelske tegnsprog baserer sig ${ }^{10}$ på Det Gamle og Det Nye Testamente, en kanon med to dele. Begge dele har deres eget centrum: den ene, sande Guds åbenbaring i Det Gamle Testamente og troen på Kristus i Det Nye Testamente. Der er en stor spænding mellem dem. Den konsekvente monoteisme tolerer slet ikke nogen anden Gud ved siden af den ene, sande Gud. Den spænding kan først løses, når den nytestamentelige tro på frelsen tolkes som en overvindelse af den monoteistiskes tros krise, idet nemlig frelsen fortolkes som en frelse gennem troen på den eneste Gud.

De to aksiomer i den bibelske tro skal suppleres med mange grundmotiver. De kan opfattes som søgeprogrammer, som mennesker benytter sig af for at opdage det i deres erfaringer i livet og i verden, som bekræfter eller modsiger disse grundmotiver. Jeg fremhæver her tre grupper af erfaringer.

Der er for det første det under, at der overhovedet er noget og ikke intet, og at alt er kontingent, d.v.s. det kunne ligeså godt ikke være eller være anderledes. Den slags kontingenserfaringer rører ved Guds mysterium som skaber.

Endvidere støder vi på vores livsverdens grænser: Menneskets endelighed, forgængelighed og fejlbarlighed. Grænser henviser altid til noget, der er på den anden side af disse grænser. Dette er indirekte transcendenserfaringer: Ved at støde på grænserne aner vi, at der er noget mere.

Fremfor alt oplever vi et dybt slægtskab med alt værende. Jeg har kaldt den slags oplevelser resonanserfaringer, fordi de bringer noget til at svinge i vores tilværelse, som er beslægtet med hele virkeligheden og som motiverer os til at bevare denne resonans og udvide den. Kærlighed er den største resonanserfaring.

Religiøse erfaringer er efter mit skøn kontingens-, grænse- og resonanserfaringer. De er indkodet i de bibelske grundmotiver. Listen over dem er åben. En liste over disse grundmotiver kunne være følgende (idet grupperingen af motiverne kun sker for overskuelighedens skyld):

Erfaringer med Gud udtrykkes gennem følgende motiver:

\section{- Skabelse og tilintetgørelse:}

Gud er den som skaber ud af intet og kan tilintetgøre alt.

10. Mere detaljeret i G. Theissen, Die Religion der ersten Christen $=$ De forste kristnes religion, men her findes ikke så mange grundlæggende motiver som i listen nedenfor. 
- Tryghed og distance:

Mennesket hviler som skabning trygt i Gud (geborgen in Gott), men samtidig er Gud fremmed for mennesket.

- Ansvar og skyld:

Mennesket er ansvarligt overfor Gud, men går fejl af sit ansvar.

Erfaringer med det skabte (verden) er:

- Visdom og kaos:

Naturen er ordnet gennem Guds visdom, men er truet af uorden.

- Frelseshistorie og resignation:

Gud åbenbarer sig i historien, men historien er også ofte meningsløs.

- Håb og katastrofer:

Der er et voksende håb, men også tiltagende katastrofer i historien.

- Under og skabne:

Alt er åbent for det, som ikke kan forudses; skæbnetroen bliver bevidst afvist i Bibelen.

Erfaringer med mennesker genfindes i følgende motiver:

- Omvendelse og forstokkethed

Mennesket har chancen for omvendelse, men vægrer sig imod al fornuft

- Eksodus og eksil:

Grupper bryder op til friheden og taber den i eksilet.

- Retfardighed og uret:

Mennesker er forpligtet til at øve retfærdighed, men skaber uret.

Der er også nogle motiver, som accentuerer mødet mellem Gud og menneske:

- Abenbaring og mysterium:

Gud træder frem fra sit mysterium, men bliver ved med at være en deus absconditus (en skjult Gud).

- Inkarnation og idolatri:

Gud tager bolig i det konkrete, men virkelighedens fragmenter bliver også absoluteret som afguder.

- Tro og vildledning:

Gud bliver tilgængelig gennem tro og tillid, men denne tro mis- 
bruges. Der findes profeter og pseudoprofeter, messias og antimessias, Gud og Satan.

- Stedfortredelse og offer:

Livet er altid et aktivt stedfortrædende liv for andre, men er også et passivt offer (victim).

- Refardiggørelse og fordommelse:

Gud anerkender ubetinget mennesket, men truer også med ubetinget fordømmelse.

Disse og andre motiver findes i mange variationer i Bibelen. De er ikke til stede i alle bibelske tekster, men danner tekstgrupper med vekslende "familieligheder" (family resemblances, som Wittgenstein kaldte dem). De er så at sige konstruktionsprincipper for "den semiotiske katedral", der er den bibelske religion, som blev opbygget af mennesker, men er bestemt til at tjene Gud. Det afgørende er: Disse grundmotiver bliver kun traderet i historien, hvis de muliggør religiøse erfaringer og hvis de bliver bekræftet igen og igen af religiøse erfaringer. Når man afsøger livet og verden ved deres hjælp, opdager man igen og igen noget, som er evident i sig selv. De åbner øjnene for erfaringer. I det følgende skal vi derfor undersøge, hvordan erfaringen af virkeligheden bliver formidlet gennem dette tegnsprog.

\section{De fire dimensioner af skriftens betydning}

Den semiotiske katedral og de tekster, som begrunder den, henviser i fire henseender til virkeligheden: til transcendensen, til historien, til livet og til fællesskabet. I den anden del af min forelæsning udfolder jeg nu skriftens firdimensionale betydning. Den minder om middelalderens firfoldige skriftbetydning, men den er noget helt andet. ${ }^{11}$ Alle fire dimensioner er baseret på den ordrette mening.

\section{Bibelens reference til transcendensen}

Bibelens reference til transcendensen er dens vigtigste dimension. Bibelens læser (når hun eller han har en religiøs interesse og ikke alene en historisk interesse) leder enten efter en kontakt med Gud eller ønsker at forstå, hvad sådan en kontakt kunne betyde for andre mennesker. Bibelen bliver på den måde læst som indkodning af religiøse erfaringer. For at få det gyldige i denne dimension frem må en bibelchen Schriftsinn”, Sacra Scripta 5 (2007), 164-191. 
hermeneutik diskutere religionskritikken: Er Gud kun en projektion af vores længsler, af vores frustrationer eller af vores vilje til magt? Derfor er spørgsmålet så vigtigt: Findes der erfaringer, som holder stand imod religionskritikken?

Filosoffen L. Wittgenstein skitserer i sin "Lecture on Ethics" (1929/30) tre religiøse grunderfaringer, som efter hans skøn er unddraget religionskritikken: ${ }^{12}$ For det første: forbavselse eller undren over verdens eksistens; for det andet: erfaringen af en absolut tryghed; for det tredje: erfaringen af skyld (jeg ville hellere tale om erfaringen af ansvar)

Undren over verdens eksistens er ikke en "mening" om verdens tilblivelse, dvs. om den blev til for 4.000 år eller milliarder af år siden. Om den slags teorier og meninger kan der diskuteres, men ikke om, at mennesker bliver grebet af undren over, at der overhovedet eksisterer noget og ikke intet. For det mysterium, at der overhovedet eksisterer noget, er uafhængigt af teorier vedrørende verdens oprindelse. Det er suverænt over for vores meninger om verdens tilblivelse.

Den anden religiøse grunderfaring er tryghed eller ubetinget tillid. Også denne erfaring sætter sig suverænt igennem imod vores meninger. Vi føler denne tryghed, når vi trøster et barn om natten og siger: "Sov godt, alt er i orden". Vi er godt klar over, at alt ikke er godt, men vi fjerner ikke barnets tillid. Wittgenstein har ikke set nogen sammenhæng mellem den første og den anden grunderfaring. Men der findes en nærliggende forbindelse: forundringen over, at der overhovedet eksisterer noget, omfatter også ens egen eksistens. Den slutter os sammen med alle ting fra de fjerneste galakser til de mest elementære partikler. Værens mysterium trænger igennem alt som en musik, der omfatter os selv. Vores eksistens er kun en tone i denne musik.

Den tredje religiøse grunderfaring er erfaringen af ansvarlighed eller samvittighed. Her møder man ikke et værensmysterium, men det forhold, at noget skulle eller burde være, ikke et Sein, men et Sollen, ikke et is, men et ought. Wittgenstein fremstiller heller ikke her nogen forbindelse med de andre religiøse grunderfaringer. Men den er evident nok: Vi oplever i forundringen over værensmysteriet også alt værendes kontingens, d.v.s. at alle ting også kunne ikke-være og ligeså godt kunne være anderledes. Erfaringen af ansvar er netop denne kontingenserfaring vedrørende vores egne gerninger: Vi kunne udmærket gøre noget andet eller helt undlade at gøre noget. Kun derfor

12. Ludwig Wittgenstein, "Vortrag über Ethik", i: Ludwig Wittgenstein, Vortrag über Ethik und andere kleine Schriften, red. J. Schulte (stw 770; Frankfurt: Suhrkamp 1989), 9-19, særligt s. 14-19. Den første udgivelse af artiklen var: "Wittgenstein's Lecture on Ethics", Philosophical Review 74 (1965) 3-12. 
føler vi os ansvarlige, og denne oplevelse er uafhængig af vores meninger om frihed og determinisme. Mens en ubetinget tryghed indlejrer os i en samhørighed med alle ting, river bevidstheden om vores ansvarlighed os voldsomt ud af denne samhørighed. Vi er anderledes end alle ting. Partikler, sten, planter og dyr har ikke nogen ansvarlighed.

Men er det ikke sandt, at religionerne udtrykker disse erfaringer ved hjælp af mærkelige myter om verdens oprindelse og tilintetgørelse? Jo, det er sandt: Religionerne benytter sig af mytiske billeder, symboler og lignelser for at kunne kommunikere den slags erfaringer. De tre religiøse grunderfaringer bliver kommunikeret i Bibelen ved hjælp af tre billeder af Gud: ${ }^{13}$ Når Bibelen taler om Gud som skaberen, henviser dette billede til det under, at der eksisterer noget og ikke intet. Når Bibelen taler om Gud som fader (og mere sjældent om Gud som moder), indkoder dette billede erfaringer af ubetinget tryghed. Når der i Bibelen er tale om Gud som herre, lovgiver og dommer, så indkoder disse billeder de imperativer, som vi ikke giver os selv. Jeg tænker på bud som: "Du må ikke dræbe! Du må ikke bryde ægteskabet!” (Ex 20,13-16).

Det er først gennem disse sproglige formuleringer, at religiøse erfaringer bliver til erfaringer af Gud. Sproglige billeder åbner øjnene for noget, som kun kan ses ved hjælp af disse billeder. Derfor kan det siges: Det er først sproget, som åbner den dybdedimension indenfor religiøse erfaringer, som vi kalder "Gud". Eller sagt med andre ord: Gud åbner sig selv gennem sproget. Derfor spiller i alle bibelske religioner ordet så stor en rolle. Alle er overbevist om, at Gud åbenbarer sig i ordet. I den kristne religion er Jesus fra Nazaret Guds ord i absolut forstand. Og derved kommer vi til skriftens anden dimension: referencen til historien.

\section{Skriftens reference til historien}

Bibelen har en helt særlig relation til Israels historie og i dennes midte til Jesus fra Nazaret. Den fortæller om Jesus i en blanding af historie og myter. De mytiske udsagn modsiger vores videnskabelige syn på verden. Det lader sig slet ikke verificere, at et menneske har været præeksistent, at det ikke blev avlet ad den gængse seksuelle vej, eller at han var i stand til at gå på vandet. Myterne er meget menneskelige tolkninger af historien. Ingen er forpligtet til at anse dem for sande i

13. Disse myter og symboler adskiller sig fra deres teologiske vurdering, som Wittgenstein kaldte "meninger". Disse teologiske ideer skal gives en større betydning end Wittgenstein har tilskrevet dem. "Symbolet inspirerer tanker" (Paul Ricoeur). Symbolet er forud for tænkningen, men det kan stimulere tænkningen. 
bogstavelig betydning. Men hvorfor er referencen til denne mytisk tolkede historie nu som før nødvendig for den kristne tro? De skyldes, at de tre grunderfaringer bliver reaktualiseret gennem den mytisk-historiske fortælling, selv om grunderfaringerne nødvendigvis hele tiden støder på grænser. ${ }^{14}$

Underet, at der eksisterer noget og ikke intet, støder på forståelsens grænser: Værensmysteriet kan ikke gennemskues. Men i Jesus Kristus, siger Det Nye Testamente, bliver Gud tilgængelig på en ny måde. Noget som har været skjult bliver åbenbart.

Tryghedens erfaring støder også på en grænse: Vi er udsat for døden og lidelsen - uden nogen som helst tryghed. Historien om Jesus overvinder også denne grænse. Den fortæller, at Kristus overvinder forgængelighed, smerter, uret og død.

Erfaringen af ansvar fører til grænsen for aktivitet: Vi svigter og bliver skyldige, netop fordi vi er frie og ansvarlige. Historien om Jesus overvinder denne grænse. Ifølge Det Nye Testamente tilsiger Jesus syndernes tilgivelse og bærer stedfortrædende menneskenes synd og skyld.

Det er det karakteristiske i Det Nye Testamente, at dets fortællinger overvinder grænser. I det følgende skitserer jeg et forsøg på at afkode denne grænseoverskridelse ved hjælp af den kognitive religionsvidenskabs kategorier (idet jeg foretager nogle modifikationer). ${ }^{15}$

Den kognitive religionsvidenskab forklarer, hvorfor religiøse forestillinger er udbredt universelt. De er nemlig en optimal blanding af kontraintuitive og intuitive ideer. Som kontraintuitivt defineres alt, som modsiger hverdagens ontologi. Allerede småbørn skelner mellem det, som er LEVENDE, og det, som er IKKE LEVENDE, endvidere mellem NATURLIGE OBJEKTER og ARTEFAKTER på den ene side (de ikke levende ting) og PLANTER, DYR OG PERSONER på den anden side (de er levende). ${ }^{16} \mathrm{Vi}$ aktiverer nogle næsten aprioriske forventninger over for disse ontologiske domæner, når vi klassificerer noget f.eks. som en

14. I modsætning til Dietrich Bonhoeffer må vi ikke devaluere sådanne oplevelser som grænsens oplevelser. Dette viser Bonhoeffers skæbne: Han var overbevisende fremfor alt ved sin adfærd i en ekstrem situation.

15. Som en introduktion kan tjene Istvan Czachesz, "Kontraintuitive Ideen im urchristlichen Denken”, i: Gerd Theissen/Petra von Gemünden red., Erkennen und Erleben. Beiträge zur psychologischen Erforschung des frühen Christentums (Gütersloh: Gütersloher Verlagshaus 2007), 197-208. Endvidere Pascal Boyer, Religion Explained. The Evolutionary Origins of Religious Thought (London: Vintage 2001) og Ilkka Pyysiäinen, How Religion Works. Towards a New Cognitive Science of Religion (Cognition and Culture 1; Leiden: Brill, 2001).

16. Den kognitive ansats i videnskaben om religionen adskiller fem basale kategorier: ting, artefakter, planter, dyr og mennesker. Men spædbørn begynder med at skelne mellem levende og livløse ting; der findes allerede her et hierarki af kategorier. 
person. Vi forventer, at personer ikke kan gå gennem materielle legemer, at de har følelser og intentioner og at de skal dø. Religiøse forestillinger modsiger sådanne forventninger: Den opstandne Kristus går igennem lukkede døre. Han er udødelig. Den kognitive ansats siger: De religiøse forestillingers kontraintuitivitet forklarer den opmærksomhed, som de fremkalder; deres indlejring i et netværk af intuitive ideer forklarer, hvorfor de overbeviser på længere sigt.

For at forstå den i Bibelen bevidnede grænseoverskridelse skal vi efter mit skøn udvide de ontologiske domæner. Religionen transcenderer ikke alene grænsen mellem materielle objekter, artefakter, planter, dyr og personer, men kontrasterer også det at være og det ikke at være, SEIN og NICHTS, selv om dette "INTET" i religionernes historie altid er et formløst "NOGET". Myter fortæller, hvordan guderne i begyndelsen har skabt verden ud af den slags “intet”. Det er først med transcenderingen af alle ontologiske domæner, at vi kan beskrive den religiøse grunderfaring: forundringen over, at der overhovedet er noget og ikke intet. Erkendelsen af, at naturen har en forbavsende orden, er for eksempel ikke i sig selv en religiøs erkendelse. Mange naturvidenskabsmænd ved det meget godt, men de bliver ikke religiøse mennesker af den grund. Men når nogen oplever denne orden på den måde, at den er kontingent og et under, så bliver det til en religiøs erfaring. Den grænseoverskridelse, som funderer alt, er transcenderingen fra intet til noget, fra ingenting til væren.

Denne overvejelse kan hjælpe os til bedre at forstå den historiske Jesus og hans transformation til den kerygmatiske Guds søn. Grænseoverskridelsen tager her to forskellige retninger - hos den historiske Jesus fra neden og opad, hos den kerygmatiske Kristus oppefra og ned.

Den historiske Jesus gør verden transparent for Gud gennem sine lignelser og symbolhandlinger og formidler ad den vej et indirekte møde med Gud. Den kerygmatiske Kristus konfronterer os direkte med den Gud, som skaber ud af intet. Han konfronterer os med den opstandne Kristus. Den historiske Jesus og den kerygmatiske Kristus svarer på den måde til to grundformer af religiøse oplevelser: ${ }^{17}$ Enten bliver vores hverdag transparent for Gud eller hverdagsverdenens orden rives i stykke og et Totaliter Aliter (noget 'helt andet') bryder ind i den. Den historiske Jesus forvandler gennem billeder og lignelser hverdagen til et slør, hvor Gud lyser igennem; den kerygmatiske Kristus river sløret itu. Den historiske Jesus står ved siden af menneskene, som leder efter Guds spor i denne verden; Jesus opfattede sig

17. Jf. min fremstilling af religiøse erfaring og adfærd af de tidlige kristne med en differentiering mellem den radikalreligiøse og den moderatreligiøse erfaring og adfærd i G. Theissen, Erleben und Verhalten der ersten Christen (note 6). 
selv utvetydigt som et menneske til forskel fra Gud. Den kerygmatiske Kristus derimod bryder ind i denne verden som Guds irriterende og fremmede spor i denne verden. I kerygmaet finder et direkte møde med væren sted, et møde med Gud sig selv. Her konfronteres vi med det under, som væren er i sig selv. Protestantismens liberale teologi ville alene gøre den historiske Jesus til basis for en fornyet kristen tro, den eksistentiale kerygmateologi ville alene vide af kerygmaet. Men begge hører sammen.

Det Nye Testamentes reference til historien om Jesus fra Nazaret er nødvendig, fordi de tre religiøse grunderfaringer ved denne historie og dens mytiske indpakning bliver fornyet - til trods for grænsen af endelighed, lidelser og synd. Hans historie bliver frem for alt ved dens mytiske ophøjelse til en grænseoverskridning. En præeksistent person kommer fra himlen, går på vandet og vender tilbage til himlen. Kan vi tro på denne myte i bogstavelig forstand? Umuligt! Denne myte er sakral poesi. Ingen bør forstå billederne ordret, selv om de er tilknyttet en historisk skikkelse, som virkelig har levet. Men at den fundamentale grænse mellem "intet" og "væren" overskrides i denne historie er sandhed.

\section{Skriftens reference til livet}

Skriftens reference til livet består i, at de fornyede religiøse grunderfaringer bliver til grundlaget for en etik og at denne vil præge hele livet. Etikkens begrundelse i religiøse erfaringer rører ved et tabu i den moderne verden. Etik skal være autonom og må ikke begrundes religiøst - for religiøse og ikke-religiøse mennesker skal samarbejde i vores samfund. Men den moderne sekulære etik har et deficit eller en mangel vedrørende sin begrundelse. Der findes ikke en Letztbegründung for etikken, det samme gælder for vores viden. Jeg mener ikke, at religionen kan levere en sådan sidste begrundelse, men religiøse erfaringer muliggør, at man lever med dette deficit. Religiøse erfaringer opdager noget, som er værdifuldt i sig selv. Vi skal endnu en gang gennemgå de tre grunderfaringer for at spørge, hvordan de kan begrunde etiske imperativer:

Eksistenserfaringen åbner en basal værdi for os: Det er godt, at der eksisterer noget som helst. At være er bedre end ikke at være. Taknemmeligheden for livet er begrundet i denne erfaring. Men inden for det empiriske liv oplever vi mange ting, som vi ikke kan være taknemmelige for. Alt er udleveret til at blive til intet. Men netop denne differens mellem den basale religiøse erfaring og det empiriske liv giver grund til et imperativ: Der skal være noget, som vi kan sige ja til. 
Det er det grundlæggende etiske imperativ: at sige ja til væren og til livet. Det er begrundet i skabelsen (H. Jonas). ${ }^{18}$

Den anden religiøse grunderfaring er slægtskabet med hele virkeligheden. Når vi føler os trygge i virkeligheden, gør vi ikke forskel på godt og ondt. Det er en erfaring, som giver afkald på at gøre forskelle, men som omfatter virkelighedens totalitet. Denne erfaring er en vigtig kilde til etikken, fordi vi i det empiriske liv altid må lave en forskel på det som hjælper og det som truer livet. Det empiriske liv er præget af konflikter. Det er denne difference mellem det religiøse slægtskab med alt og konflikten mellem alt liv, som frembringer et imperativ: Ikke at leve imod andre men i samarbejde med dem! Jeg har kaldt det det "antiselektive imperativ" (eller det "antiselektionistiske imperativ"), som kræver, at vi reducerer selektionens tryk, som medfører konkurrence og konflikt. Det er dette imperativ, som er grundlaget for al menneskelig kultur, men som blev klart formuleret i Bibelen som buddet om kærlighed.

Den tredje religiøse grunderfaring er ansvarligheden. Den er grundlaget for et tredje imperativ: Fordi vores gerninger er ligeså kontingente som eksistensen overhovedet, oplever vi os som frie væsener. Vi er intet over for det utrolig store univers, men vi har evnen til at lade noget blive til ud af intet. Det giver os en særstilling som skaberens billede. Vi skal respektere den samme evne i alle mennesker: Alle kan begynde noget, som uden et menneskeligt initiativ ikke ville eksistere (ligesom Gud ved verdens begyndelse påbegyndte noget). Men dette støder i den empiriske livsverden på faktiske indskrænkninger af den menneskelige frihed. Dette giver grundlaget for et "libertært" imperativ, et frihedens imperativ: Vi er forpligtet til at muliggøre frihed $-\mathrm{i}$ vores liv og $\mathrm{i}$ de andres liv.

Af de tre religiøse grunderfaringer kan udledes taknemmelighed for livet, kærlighed på grund af en beslægthed med alt og en vilje til frihed. Ja til livet, medmenneskelighed og autonomi er tre grundlæggende værdier, som er baseret i de tre grunderfaringer eller som i det mindste bliver bekræftet og fornyet gennem dem. Grundlaget for de tre imperativer er altid en difference mellem en religiøs erfaring og den empiriske verden.

Kan man bringe disse tre imperativer på en fællesnævner? For at få de religiøse grunderfaringers etiske betydning frem kan vi tolke dem som resonanserfaringer: Underet, at der overhovedet eksisterer noget,

18. Jf. med henblik på dette basale imperativ Hans Jonas, Das Prinzip Verantwortung, Versuch einer Ethik für die technologische Zivilisation (Frankfurt: Suhrkamp 1979), fremfor alt "Sein und Sollen" (s. 153ff) med afsnittet: "Das Ja des Lebens emphatisch als Nein zum Nichtsein" (s. 156f) eller: "Sollenskraft des ontologischen Ja für den Menschen" (s. 157f). 
har en resonans i, at vi er. Eksistensens kontingens har en resonans i vores eget livs kontingens. Det at føle sig tryg er oplevelsen af en stor resonans: $\mathrm{Vi}$ er materie ligesåvel som al anden materie, vi deler den samme genetiske kode med alle levende væsener, vores tanker følger strukturer, der korresponderer med strukturer i hele verden. Vores intelligens er et svagt ekko af en meget større intelligens i skabelsen. $\mathrm{Og}$ vi er fremfor alt et ekko af eksistensens under, fordi vores gerninger er ligeså kontingente som det værende overhovedet. Det vil sige: Alle tre religiøse grunderfaringer er resonanserfaringer. De er baseret $\mathrm{i}$ en beslægtethed mellem os og virkeligheden. Disse resonanserfaringer omfatter naturens orden, livets under, relationerne mellem mennesker. Det er afgørende for os, at alle resonanserfaringer indebærer en etisk forpligtelse til at opdage denne form for resonans, at bevare den og at forøge den. Det som jeg har opridset i abstrakte termer som et grundlag for en etik, vil jeg nu sammenfatte ved hjælp af en meditativ tekst, som jeg engang har formuleret:

At leve som svar ${ }^{19}$

I religionen går det os som det menneske, der om vinteren tager på skiferie $\mathrm{i}$ alperne.

Du nærmer dig stedet og landskabet $\mathrm{i}$ håb om frisk luft og motion.

Du bruger alpelandskabet på at komme til kræfter.

Men når du en morgen står foran det uberørte snelandskab, og solens lys făr det til at glitre i et forklaret skær, så aner du en tilskyndelse til at tegne en særlig kurve i sneen, for at yde denne skønhed retfærdighed.

Alt andet forekommer dig at være en forseelse imod landskabet.

Du hører i det en appel.

Du spørger ikke mere, om det svarer til dit behov.

Du bliver engageret af landskabet for at fuldende det.

Sådan går det os i religionen.

Vi befinder os i vores daglige virkelighed, forfølger vores mål i den og spørger, om den svarer til vores behov.

Lige indtil vi erfarer en omvending.

En mægtig appel bevæger os til at forstå vores liv som et svar og

făr os til ikke mere at spørge,

om virkeligheden svarer til vores behov, men om vi svarer på dens udfordringer.

19. Oversættelsen stammer fra Hanne Davidsen og Sanne Thøisen. Den indgår i en samling af mine meditative tekster, der skal publiceres på dansk. 
Alle etiske orienteringer gennemgår en krise på grund af verdens etiske irrationalitet. Bibelen viser en vej til, hvordan de kan fornyes til trods for denne krise, når de er strandet ved grænserne af endelighed, lidelse og synd. Denne fornyelse skyldes Kristus: troen på ham er et mod og en motivation til livet, som blev korsfæstet sammen med Kristus og genoprejst sammen med ham som en ny skabelse. Det er gennem denne transformation, at de grundlæggende etiske imperativer bliver fornyet: Imperativet til væren samt det antiselektive og libertære imperativ, der ligger til grund for vores etik. Men etikken er ikke den eneste basis for fællesskabet. En anden basis er skriften og ritualerne.

\section{Skriftens relation til fallesskabet}

Bibelen har en kanonisk funktion: Den er den normative basis for en religion, d.v.s. at religionens tegnsystem igen og igen bliver rekonstrueret ud fra skriften. For så vidt som den har en normativ betydning, forbinder og afgrænser den grupper: Jeg tager her kun ét problem op. Bibelen forbinder tre monoteistiske religioner: jødedommen, kristendommen, islam, men Det Nye Testamentes kristologiske budskab adskiller dem. Er det muligt at disse tre religioner kan blive enige om en gudsforståelse? Og hvordan forholder det sig med de kosmiske og mystiske østlige religioner?

Inden for troen på den ene, sande Gud vi har adskilt tre grunderfaringer: virkelighedens kontingens, forbundetheden med hele virkeligheden og ansvarlighed. Vi kan tilskrive de tre bibelske religioner en dominans af en af disse tre erfaringer:

Vi skylder jødedommen bevidstheden om ansvar. Moses konfronterer folket med et ubetinget krav. Toraen bliver til et symbol for menneskets ansvarlighed. Men Det Gamle Testamentes Gud er samtidig menneskets skaber og beskytter. Tænk på Salme 23: "Herren er min hyrde".

Kristendommen har først og fremmest oplevet Gud i forbindelse med en stærk tryghedsfølelse. Det er karakteristisk, hvad Paulus siger: "For jeg er vis på, at hverken død eller liv eller engle eller magter eller noget nuværende eller noget kommende eller kræfter eller noget i det høje eller i det dybe eller nogen anden skabning kan skille os fra Guds kærlighed i Kristus Jesus, vor Herre” (Rom 8,38f).

Islam accentuerer afhængighedsbevidstheden. Gud er den, som skaber alt. Alting er kontingent. Her mødes en stærk bevidsthed om det skabte: "Han er Himlens og jordens skaber. Når han har besluttet sig 
til noget, siger han: Det skal blive til! Og det bliver til!" (Sura 2.117). Guds skabelsesmagt bestemmer alt igen og igen, forfra. Alt er en kontinuerlig creatio ex nibilo. Naturens love er kun Guds sædvaner, som han altid kan gennembryde. Men samtidig er Gud den barmhjertige - det er hans vigtigste prædikat.

Billederne af Gud er utvivlsomt forskellige, men de kan tolkes i retning af en og den samme realitet. Monoteismen (og de tre religiøse grunderfaringer) kan derfor forene de bibelske religioner. Det, som adskiller dem, er fremfor alt det andet bibelske aksiom: troen på Jesus fra Nazareth, som samtidig begrunder kristendommens identitet. Men der er også i kristologien en større chance for en tolerance, der forbinder religionerne, end mange tænker.

Den historiske Jesus, således som den kritiske forskning har rekonstrueret hans budskab, forkynder en konsekvent monoteisme. Han indordner sig utvetydigt på menneskenes side, han opfatter sig selv som et menneske med et budskab fra Gud. Endvidere tilhører Jesus jødedommen. Det er denne Jesus, som Islam respekterer som monoteismens repræsentant. Den historiske Jesu er i stand til at forbinde de tre bibelske religioner.

Men den kerygmatiske Kristus, som vi møder i Johannesevangeliet og hos Paulus står ved siden af den eneste Gud. Han afgrænser kristendommen fra jødedommen og islam. Han forbinder til gengæld kristendommen med de østlige mystiske og kosmiske religioner. For alle udsagn om en "Kristus inden i os" eller om en "kosmisk Kristus", som er tilstedeværende i alle ting, forudsætter den ophøjede Kristus. Det er kun ved den ophøjede Kristus, at det er muligt at udkaste en Kristusmystik. Kun den ophøjede kan være nærværende overalt, hvor der er to eller tre samlet $\mathrm{i}$ hans navn (Matt 18,20).

Men hvordan kan en tolkning af Bibelen præget af en interreligiøs tolerance udvikles på en overbevisende måde - til trods for det absolutte krav, som Der Nye Testamente indebærer? Jeg giver mit svar ved hjælp af et mytisk billede: Ved dagenes ende, når det himmelske videnskabernes akademi opfordrer alle forskere til ud fra mange tekster og traditioner at danne en endegyldig kanon af de tekster, som er gyldige i al evighed, så vil mange bibelske tekster være med - men også andre tekster. Jeg vover ikke at sige, hvilke tekster det er. Men foreløbig kunne religionerne på jorden gøre deres tolerance og åbenhed over for hinanden mere overbevisende, hvis de i deres hellige skrifter indoptog et tillæg med tekster fra andre religioner, som de enten kan samtykke i eller som er så fremmede, at de kan lære noget af dem. Der findes tekster med en mulig konsensus eller konvergens, og der findes komplementære tekster. Jeg er overbevist om, at kun så- 
dan en kanon med en antologi af interreligiøse apokryfe tekster vil kunne overbevise på længere sigt. For den moderne bevidsthed tilskriver kun religionen sandhed, hvis noget af denne sandhed kan genfindes $\mathrm{i}$ alle religioner. For at sige det rent ud: Religionerne vil kun kunne opretholde deres krav på gyldighed, hvis de giver afkald på deres absolutte gyldighedskrav - ligesom videnskaben har givet afkald på en sidstebegrundelse (Letztgültigkeitsanspruch) netop for at kunne forsvare sin gyldighed. ${ }^{20}$

Til slut vil jeg vende tilbage til det billede jeg benyttede mig af $\mathrm{i}$ begyndelsen: Religion og religioner er semiotiske katedraler. De tjener til at dyrke Gud, men de blev skabt af mennesker. Bibelen rummer vidnesbyrd om erfaringer med Gud, den fortæller i mytisk form historien om Jesus, den formulerer etiske bud og grundlægger religiøse riter. Alt dette er menneskelige konstruktioner. Men ved hjælp af disse konstruktioner er vi i stand til at opdage noget i virkeligheden, som vi ikke har konstrueret. De bibelske aksiomer og grundmotiver er søgeprogrammer med henblik på at afsøge virkeligheden og opdage dens religiøse dybde: $\mathrm{Vi}$ opdager ad den vej tegn, som viser hen til Gud. Bibelen indeholder mange sådanne opdagelsesprogrammer. Den er ikke et afsluttet system, som kun refererer til sig selv, men den henviser til et Totaliter Aliter. Bibelen kan nu som før tjene til at optage en dialog med Gud. Heinrich Heine siger med fuld ret om Bibelen: "Wer seinen Gott verloren hat, der kann ihn in diesem Buche wiederfinden, und wer ihn nie gekannt, dem weht hier entgegen der Odem des göttlichen Wortes." 21 "Den, der har tabt sin Gud, kan genfinde ham i denne bog, og den, der aldrig har kendt ham, mod ham blæser det guddommelige ord ånde."

20. I begyndelsen formulerede jeg tre kriterier for en positiv forståalse af Bibelen i dag: tolerance, fornuft og autonomi eller myndighed. Det tilhører autonomien, at folk nu forstår, at vi har frihed til at bestemme vores afstand eller nærhed til alle religiøse billeder. Teologien skal bidrage hertil ved at vise, at der altid er flere muligheder for en forståelse af Gud og en forståelse af Jesus. Jeg har også formuleret to negative kriterier for en moderne bibelske hermeneutik: Bibelen bør ikke reduceres til ét emne. Bibelen vidner om mange aksiomer og grundlæggende motiver. Den har i det mindste fire dimensioner. En moderne bibelsk hermeneutik bør heller ikke være eksorcistisk, men skal kunne udvikle en kærlighed til jødedommen, myten og den menneskelige autonomi.

21. Heinrich Heine, "Zur Geschichte der Philosophie und Religion in Deutschland. Vorrede zur zweiten Auflage 1852", i: Heinrich Heine, Beiträge zur deutschen Ideologie (Frankfurt: Suhrkamp 1972), 7. 